This article is (c) Emerald Group Publishing and permission has been granted for this version to appear here (https://dspace.lib.cranfield.ac.uk/index.jsp). Emerald does not grant permission for this article to be further copied/distributed or hosted elsewhere without the express permission from Emerald Group Publishing Limited. www.emeraldinsight.com

"Customer Perceptions on Logistics Outsourcing in the European Consumer Goods Industry" International Journal of Physical Distribution \& Logistics Management Vol. 34 No.8 (2004) pp 628-624.

\title{
CUSTOMER PERCEPTIONS ON LOGISTICS OUTSOURCING IN THE EUROPEAN CONSUMER GOODS INDUSTRY
}

\section{Authors:}

Richard Wilding

Centre for Logistics and Supply Chain Management, Cranfield School of Management, U.K.

\section{Rein Juriado}

Faculty of Economics and Business Administration, Tartu University, Estonia. 


\section{CUSTOMER PERCEPTIONS ON LOGISTICS OUTSOURCING IN THE EUROPEAN CONSUMER GOODS INDUSTRY}

Richard Wilding, Ph.D, is a Senior lecturer in Logistics and Supply Chain Management at Cranfield School of Management, UK. He is a member of the Agile Supply Chain Research Centre at Cranfield and specializes in techniques to enable agility. His research into chaos and complexity in the supply chain and millennium stocking policies has received international media coverage including radio and television appearances. He can be reached at Cranfield Centre for Logistics and Supply Chain Management, Cranfield School of Management, Cranfield University, Cranfield, Bedfordshire, UK. Tel: + 44 (0)1234-751122

E-mail: richard.wilding@cranfield.ac.uk Web: www.richardwilding.info

Rein Juriado, M.Sc, lectures in Logistics and Export Management at Tartu University, Estonia. His research interests include Logistics Outsourcing and Air Transport Management. He was awarded the Directors' Prize for his performance during his Master studies at Cranfield University, UK. He can be reached at Tartu University, Faculty of Economics and Business Administration, 4 Narva road, 51009 Tartu, Estonia.

Tel.: +372 7376116 .

E-mail: rein.juriado@ut.ee 


\title{
CUSTOMER PERCEPTIONS ON LOGISTICS OUTSOURCING IN THE EUROPEAN CONSUMER GOODS INDUSTRY
}

\begin{abstract}
This paper investigates customer perceptions on three key logistics outsourcing decisions: why to outsource, what to outsource and how to manage satisfaction within third party logistics providers (3PLs) partnerships. In addition to an analysis of the current literature, a Europe-wide postal and telephone survey revealed that outsourcing in the consumer good industry is heavily service driven and focused on the traditional logistics functions.

The key findings of the work are that cost aspects play a smaller role for outsourcing in the consumer goods industry than anticipated, and that performance measurement systems will require increased sophistication over the coming years. We also found a considerable number of consumer goods companies admitting that soft issues, such as cultural incompatibility and poor communication, may lead to the failure of the $3 \mathrm{PL}$ partnership.
\end{abstract}

Keywords: customer perception, logistics, outsourcing, consumer goods

\section{Introduction}

This paper discusses logistics outsourcing decisions in the European consumer goods industry. Outsourcing or third party logistics is generally defined as the provision of a single or multiple logistics services by a vendor on a contractual basis (Razzaque \& Sheng 1998). The providers of these services are generally referred to as 3PLs (third party logistics providers). Some definitions of outsourcing contain additional constraints, for example, on the minimum number of services acquired and the minimum duration of the contract (Bradley 1994 and Laarhoven et al. 2000).

Over the past few decades, the European consumer goods industry has experienced a power shift from manufacturers and suppliers to retailers, growing emphasis on service and pressure to further cut the level of inventory. Managing consumer goods companies in this increasingly demanding environment has made many firms turn to 3PLs for assistance. 3PLs are used for traditional logistics functions, such as transport or warehousing and for other services, such as reverse logistics. It has been estimated that about $40 \%$ of the global logistics is outsourced (Wong et al. 2000).

This study aims to identify the customer perceptions on key logistics outsourcing decisions in the consumer goods industry. In the context of this research, the key outsourcing decisions are: 
- Why outsource?

- What logistics functions should be outsourced?

- How to manage satisfaction within a 3PL partnership?

The paper will present a literature review identifying a number of research questions that need to be addressed within the context of this environment. It proceeds to outline the research method used and finally it reviews the results of the survey, carried out as a part of this study, in the context of other academic research.

\section{Literature review}

\subsection{Why Outsource?}

In this section we give an overview of previous academic works on outsourcing and aim to identify the specific topics in logistics outsourcing that require further investigation.

The first of the three questions addressed in this article is why do companies outsource. Table 2.1 gives an overview of the main reasons as established by five previous studies (P-E International 1994, Boyson et al. 1999, Fernie 1999, Laarhoven et al. 2000, Penske Logistics 1999). Since different studies use different wording to refer to generically same or similar reasons, the first column is classificatory, indicating the area.

The table includes double ranking. First, authors of the cited studies ranked the reasons. Second, for the purpose of this research, an overall ranking was calculated. This was done by awarding 10 points to the top reason identified by each author, 8 points to the second highest reason, 6 to the third, 5 to the fourth and 4 to the fifth. For each of the studies, ranking 1 before a reason means that the largest share of companies surveyed claimed that particular reason to be their primary motivator for outsourcing, ranking 2 means that the second largest share of companies outsource for that reason etc. The points were summed up and are presented in the right-hand column.

The maximum score in Table 2.1 could be 50, in which case all five studies would have found the same reason to be the top driver for outsourcing. The table shows that cost reduction (40 points), improvement of service levels (27), increase in operational flexibility (26), focusing on core competencies (17), improvement of asset utilisation (16) and change management (16) are the most common reasons for outsourcing. We will attempt to assess in the empirical part of the study whether the main reasons for outsourcing in the consumer industry match these reasons. 
Table 2.1. Reasons for outsourcing - summary of previous surveys

\begin{tabular}{|c|c|c|c|c|c|c|}
\hline Type of reason & $\begin{array}{l}\text { P-E International } \\
\text { (1994): consumer } \\
\text { goods industry }\end{array}$ & $\begin{array}{l}\text { Boyson et al. (1999): } \\
\text { all industries }\end{array}$ & Fernie (1999)*: retailers & $\begin{array}{l}\text { Laarhoven et al. } \\
\text { (2000): wide range } \\
\text { of industries }\end{array}$ & $\begin{array}{l}\text { Penske Logistics } \\
\text { (1999): several } \\
\text { industries }\end{array}$ & Score \\
\hline $\begin{array}{l}\text { 1. Cost or revenue } \\
\text { related }\end{array}$ & 3. Reduce costs & $\begin{array}{l}\text { 1. Cost saving or } \\
\text { revenue enhancement }\end{array}$ & $\begin{array}{l}\text { 5. Tends to be more cost } \\
\text { efficient }\end{array}$ & 1. Cost reduction & 1. Reduce costs & 40 \\
\hline 2. Service related & $\begin{array}{l}\text { 2. Improve service } \\
\text { levels }\end{array}$ & & $\begin{array}{l}\text { 4. Provides more "specialist } \\
\text { services" }\end{array}$ & $\begin{array}{l}\text { 2. Service } \\
\text { improvement }\end{array}$ & $\begin{array}{l}\text { 3. Improved } \\
\text { service levels }\end{array}$ & 27 \\
\hline $\begin{array}{l}\text { 3. Operational } \\
\text { flexibility related }\end{array}$ & 1. Flexibility & & $\begin{array}{l}\text { 1. Provides more flexible } \\
\text { system }\end{array}$ & $\begin{array}{l}\text { 3. Strategic } \\
\text { flexibility }\end{array}$ & & 26 \\
\hline $\begin{array}{l}\text { 4. Business focus } \\
\text { related }\end{array}$ & $\begin{array}{l}\text { 5. Non-core } \\
\text { activity }\end{array}$ & $\begin{array}{l}\text { 2. Outsourcing non- } \\
\text { core business }\end{array}$ & & 4. Focus on core & & 17 \\
\hline $\begin{array}{l}\text { 5. Asset utilisation } \\
\text { or efficiency } \\
\text { related }\end{array}$ & & & $\begin{array}{l}\text { 2. Allows financial resources } \\
\text { to be concentrated on } \\
\text { mainstream business }\end{array}$ & & $\begin{array}{l}\text { 2. Increased } \\
\text { efficiency }\end{array}$ & 16 \\
\hline $\begin{array}{l}\text { 5. Change } \\
\text { management } \\
\text { related }\end{array}$ & & $\begin{array}{l}\text { 4. Re-design or re- } \\
\text { engineering the } \\
\text { supply chain }\end{array}$ & & $\begin{array}{l}\text { 5. Change } \\
\text { implementation }\end{array}$ & $\begin{array}{l}\text { 4. Overall } \\
\text { improvement of } \\
\text { distribution }\end{array}$ & 16 \\
\hline $\begin{array}{l}\text { 7. 3PL expertise } \\
\text { related }\end{array}$ & & & $\begin{array}{l}\text { 3. Exploits management } \\
\text { expertise of contractors }\end{array}$ & & & 6 \\
\hline 7. Problem related & & $\begin{array}{l}\text { 3. Outsourced area } \\
\text { was a major problem } \\
\text { for the company }\end{array}$ & & & & 6 \\
\hline $\begin{array}{l}\text { 9.Investment } \\
\text { related }\end{array}$ & $\begin{array}{l}\text { 4. Avoid } \\
\text { investment }\end{array}$ & & & & & 5 \\
\hline
\end{tabular}

* Note: in Fernie (1999) the survey distinguished transport and warehousing. For compiling this table, the average score of the two was calculated to identify the top 5 overall reasons for outsourcing. 


\subsection{What Logistics functions should be outsourced?}

The second major outsourcing related question is: what logistics activities should be outsourced? Table 2.2 summarises the findings of five previous studies on the issue (Dapiran et al. 1996, Laarhoven et al. 1998, Boyson et al. 1999, MMH 2001, Sohail \& Sohal 2003). The percentages in brackets refer to the share of companies that use a 3PL on that particular activity. The following conclusions can be drawn from Table 2.2:

- All five studies found that certain aspects of transport are outsourced to a large degree.

- There are considerable differences in the level that third parties are used on warehousing.

- Information systems have a low priority in outsourcing. This is in sharp contrast with the fact that many 3PL wish to provide IT related services and have made large-scale investments in information technology.

- Almost any logistics activity can be outsourced. For any logistics activity that researchers have included in their surveys, there has always been at least one company outsourcing that function.

Most of the articles referred to in Table 2.2 do not specify the criteria used to identify the outsourced areas. It can be assumed that in most cases operations where a third party is used in any way are classified as outsourced. However, this does not necessarily mean that the entire operation is outsourced. Especially in warehousing and areas involving advanced technology, a combination of in-house and third party operations is very likely.

According to Millen et al. (1997) outsourcing should not be seen as an "all or nothing" kind of decision. Their analysis suggests that a mixed system, combining the use of inhouse and third party facilities, may prove the best. A recent study among transport managers in the US food industry also found that $38 \%$ the companies have outsourced between 25 and $99 \%$ of their transport (Food Logistics 2002). These arguments lead to the question of whether logistics outsourcing decisions are perceived as "all or nothing" propositions or do companies prefer the combined use of 3PL and in-house resources.

While many studies look at what companies outsource, few researchers have so far addressed the issue of what logistics functions should be kept in-house. Therefore we will try to assess which logistics functions are perceived as the best and the worst suited for outsourcing by the European consumer goods companies. 
Table 2.2. Outsourced logistics areas - summary of academic works

\begin{tabular}{|c|c|c|c|c|c|}
\hline $\begin{array}{l}\text { Category of } \\
\text { logistics function }\end{array}$ & $\begin{array}{l}\text { Dapiran et al. } \\
\text { (1996): wide range } \\
\text { of industries }\end{array}$ & $\begin{array}{l}\text { Laarhoven et al. } \\
\text { (1998): wide range } \\
\text { of industries }\end{array}$ & $\begin{array}{l}\text { Boyson et al. (1999): all } \\
\text { industries }\end{array}$ & $\begin{array}{l}\text { MMH (2001): wide range } \\
\text { of industries }\end{array}$ & $\begin{array}{l}\text { Sohail \& Sohal } \\
(\mathbf{2 0 0 3 ) :} \\
\text { manufacturers }\end{array}$ \\
\hline $\begin{array}{l}\text { Transport and } \\
\text { shipment related }\end{array}$ & $\begin{array}{l}\text { Fleet management } \\
(53 \%) \\
\text { Shipment } \\
\text { consolidation }(42 \%) \\
\text { Carrier selection } \\
(27 \%) \\
\end{array}$ & $\begin{array}{l}\text { Line haul }(81 \%) \\
\text { Network based } \\
\text { transport }(70 \%) \\
\text { Emergency transport } \\
(70 \%)\end{array}$ & $\begin{array}{l}\text { Freight payment \& } \\
\text { auditing }(57 \%) \\
\text { Carrier selection \& Rate } \\
\text { negotiation }(24 \%) \\
\text { Shipment planning }(18 \%) \\
\text { Fleet management }(17 \%)\end{array}$ & $\begin{array}{l}\text { Direct transport services } \\
(63 \%) \\
\text { Freight payment }(52 \%) \\
\text { Shipment consolidation } \\
(48 \%) \\
\text { Carrier selection }(44 \%) \\
\end{array}$ & $\begin{array}{l}\text { Shipment } \\
\text { consolidation }(58 \%) \\
\text { Fleet management \& } \\
\text { operations }(49 \%) \\
\text { Freight payment }(42 \%) \\
\text { Carrier selection }(39 \%) \\
\end{array}$ \\
\hline $\begin{array}{l}\text { Warehousing and } \\
\text { inventory related }\end{array}$ & $\begin{array}{l}\text { Warehouse } \\
\text { management }(47 \%) \\
\text { Order fulfilment } \\
(33 \%) \\
\text { Order processing } \\
(16 \%)\end{array}$ & $\begin{array}{l}\text { Storage }(87 \%) \\
\text { Order picking }(79 \%) \\
\text { Inventory } \\
\text { administration }(64 \%)\end{array}$ & $\begin{array}{l}\text { Warehouse operations } \\
(29 \%) \\
\text { Inventory management } \\
(8 \%)\end{array}$ & $\begin{array}{l}\text { Warehouse management } \\
(60 \%)\end{array}$ & \begin{tabular}{|l} 
Warehouse \\
management \& \\
operations (33\%) \\
Order fulfilment (30\%) \\
Inventory \\
replenishment (24\%)
\end{tabular} \\
\hline $\begin{array}{l}\text { Information } \\
\text { systems related }\end{array}$ & $\begin{array}{l}\text { Logistics } \\
\text { information systems } \\
(22 \%)\end{array}$ & $\begin{array}{l}\text { Tracking and tracing } \\
(64 \%) \\
\text { Order entry }(11 \%) \\
\text { Forecasting }(2 \%)\end{array}$ & $\begin{array}{l}\text { Information systems } \\
(20 \%)\end{array}$ & $\begin{array}{l}\text { Tracking and tracing } \\
(33 \%)\end{array}$ & $\begin{array}{l}\text { Logistics information } \\
\text { systems }(21 \%)\end{array}$ \\
\hline $\begin{array}{l}\text { Other (related to } \\
\text { value added } \\
\text { services) }\end{array}$ & $\begin{array}{l}\text { Product returns } \\
(33 \%) \\
\text { Product assembly \& } \\
\text { installation }(13 \%) \\
\end{array}$ & $\begin{array}{l}\text { Labelling (52\%) } \\
\text { Customisation (26\%) } \\
\text { Assembly (19\%) }\end{array}$ & $\begin{array}{l}\text { Packaging }(15 \%) \\
\text { Product returns }(15 \%)\end{array}$ & $\begin{array}{l}\text { Freight forwarding }(46 \%) \\
\text { Customs brokerage }(41 \%)\end{array}$ & Product returns $(20 \%)$ \\
\hline
\end{tabular}

Note: percentages refer to the share of companies outsourcing these logistics functions as identified by the five studies. 


\subsection{How to manage satisfaction within a 3PL partnership}

The third major question addressed in this paper is how to manage a 3PL partnership. Previous studies addressing this question include P-E International 1994, Millen et al. 1997, Boyson et al. 1999, Laarhoven 2000, Murphy \& Poist 2000. Table 2.3 summarises these studies. The following conclusions can be drawn from Table 2.3:

- Users of third party logistics services are usually satisfied with their 3PLs. However, most studies do not address the details of their satisfaction. Of the five studies presented in Table 2.3, only Millen et al. (1997) go in more depth and discuss satisfaction with specific aspects of the 3PL relationship. Therefore we will study satisfaction with 3PLs from five facets of the partnership.

- Exchange of information between the logistics service provider and user, clarity of contracts and the monitoring and measuring of 3PL performance are common themes in most studies analysing the success factors in 3PL partnerships. Ideally, the set of performance measures should cover a full range of angles: cost, service, productivity, asset management, and customer and employee satisfaction (Fawcett \& Cooper 1998). Most studies stress the importance of performance measurement, yet it remains often unspecified which KPIs are or should be used.

- The main reasons for 3PL relationships to fail relate to cost and poor communication. However, it must be said that previous research has primarily focused on the success factors rather than the reasons for failure of 3PL partnerships. Murphy \& Poist (2000) argue that factors or determinants in unsuccessful 3PL relationships should be further investigated. Therefore we will attempt to pinpoint the main reasons for 3PL relationships to fail. 
Table 2.3. Managing a 3PL partnership - summary of academic studies

\begin{tabular}{|c|c|c|c|c|c|}
\hline $\begin{array}{l}\text { Factors affecting } \\
\text { the partnership }\end{array}$ & \begin{tabular}{|l|} 
P-E International \\
(1994): consumer goods \\
industry
\end{tabular} & $\begin{array}{l}\text { Millen et al. (1997): } \\
\text { all industries }\end{array}$ & $\begin{array}{l}\text { Boyson et al. (1999): } \\
\text { all industries }\end{array}$ & $\begin{array}{l}\text { Laarhoven et al. } \\
\text { (2000): wide range of } \\
\text { industries }\end{array}$ & $\begin{array}{l}\text { Murphy \& Poist (2000): } \\
\text { all industries }\end{array}$ \\
\hline $\begin{array}{l}\text { Overall satisfaction } \\
\text { with outsourcing }\end{array}$ & $\begin{array}{l}75 \% \text { of users are } \\
\text { satisfied. Manufacturers } \\
\text { are more satisfied than } \\
\text { retailers. }\end{array}$ & $\begin{array}{l}\text { Over } 90 \% \text { are satisfied } \\
\text { with impact of 3PLs on } \\
\text { costs, logistics system } \\
\text { performance and } \\
\text { customer satisfaction. }\end{array}$ & Not addressed. & $\begin{array}{l}\text { Over } 50 \% \text { of users call } \\
\text { their partnership } \\
\text { "highly successful" and } \\
\text { the contract renewal } \\
\text { rate is high. }\end{array}$ & $\begin{array}{l}\text { Logistics service users } \\
(77 \%) \text { are less satisfied } \\
\text { than providers }(82 \%) \\
\text { with their partnerships. }\end{array}$ \\
\hline $\begin{array}{l}\text { Key success factors } \\
\text { and/or causes for } \\
\text { failures }\end{array}$ & $\begin{array}{l}\text { Success: Avoiding "hire- } \\
\text { and-fire" approach, build } \\
\text { partnerships. } \\
\text { Failure: Poor exchange } \\
\text { of information, level of } \\
\text { cost, management issues. } \\
\text { 3PL users admit their } \\
\text { part of the blame } \\
\text { (insufficient controls, } \\
\text { poorly specified } \\
\text { contracts). }\end{array}$ & $\begin{array}{l}\text { Success: Clear } \\
\text { definition of service, } \\
\text { informing 3PL about } \\
\text { company policies and } \\
\text { requirements. }\end{array}$ & $\begin{array}{l}\text { Success: Information } \\
\text { sharing and } \\
\text { cooperative } \\
\text { monitoring } \\
\text { (performance metrics, } \\
\text { joint review meetings } \\
\text { etc.) } \\
\text { Failure: unclear } \\
\text { estimation of internal } \\
\text { costs. }\end{array}$ & $\begin{array}{l}\text { Success: well defined } \\
\text { requirements, } \\
\text { procedures and } \\
\text { systems; close } \\
\text { relationship; top } \\
\text { management } \\
\text { involvement; clear } \\
\text { separation of } \\
\text { responsibilities; strong } \\
\text { performance } \\
\text { orientation. }\end{array}$ & $\begin{array}{l}\text { Success: customer } \\
\text { orientation and } \\
\text { dependability are most } \\
\text { important. } \\
\text { Cost savings are more } \\
\text { important to users } \\
\left.\text { (ranked } 7^{\text {th }}\right) \text { than } \\
\text { providers }\left(12^{\text {th }}\right) \text {. Control } \\
\text { and performance } \\
\text { appraisal are more } \\
\text { important to providers } \\
\left(6^{\text {th }}\right) \text { than users }\left(15^{\text {th }}\right) .\end{array}$ \\
\hline
\end{tabular}




\section{Research methodology}

In order to clarify questions raised within the literature review, we developed a questionnaire addressing the issues in need of further examination. The survey form was sent to consumer goods companies all around Europe. A number of semistructured interviews with logistics consultants and managers working in the industry were undertaken. Such a mixed approach, combining a written questionnaire with telephone or face-to-face interviews, provides a comprehensive set of data. The quantitative data generated by the questionnaire responses is easily processed on a statistical software package while the qualitative data gathered during the interviews adds further insights on the subject.

The majority of companies were contacted by telephone before the survey form was sent out to ensure that an appropriate person - usually the logistics manager - receives it. If in three weeks the response had not been received, the companies were telephoned once more to check whether the questionnaire had been received. If not, the questionnaire was mailed for the second time. A cover letter accompanied the questionnaire form explaining the purpose and the reach (Europe-wide) of the study. A self-addressed prepaid envelope was enclosed for mailed forms.

The statistical population of the survey was made up of all European consumer goods companies. A total of 330 questionnaires were sent out, primarily in the UK, France and Germany. The addressees of the survey were randomly chosen from the electronic Amadeus database (http://amadeus.bvdep.com/ip). 52 responses were received within the specified timeframe. 50 of the returned forms were usable. This gave a response rate of $15 \%$. The UK, France and Belgium represent $78 \%$ of all responses. It may hence be argued that the responses are biased towards North-western Europe. However, it should be noted that the country of origin does not necessarily coincide with the only or main location of the company: most firms operate in more than one country.

\section{Findings of the survey}

\subsection{Introduction}

In this section we discuss the findings of our study. The remainder of the introduction outlines the profile of the survey respondents. The rest of the section is structured such that each part is dedicated to one of the three research questions: why to outsource, what to outsource and how to manage a 3PL partnership.

The largest share of survey respondents operate in the fast-moving consumer goods sector (46\% in non-food and $44 \%$ in food), with just over a quarter $(26 \%)$ being in the fashion business. The majority of firms are involved in retailing (54\%) or manufacturing (52\%). $16 \%$ of the respondents are wholesalers. Since companies were 
asked to list all of their industry types and core competencies, the percentages add up to over 100 .

The share of current logistics budget outsourced ranges from $0 \%$ to $100 \%$. Such a high degree of variation implies that the results provide a comprehensive picture of the entire industry, not only that of the companies relying heavily on outsourcing. Figure 4.1 demonstrates that the largest share of companies have outsourced between 30 and $50 \%$ of their logistics budget. Complete or nearly complete outsourcing (over $90 \%)$ is exceptional.

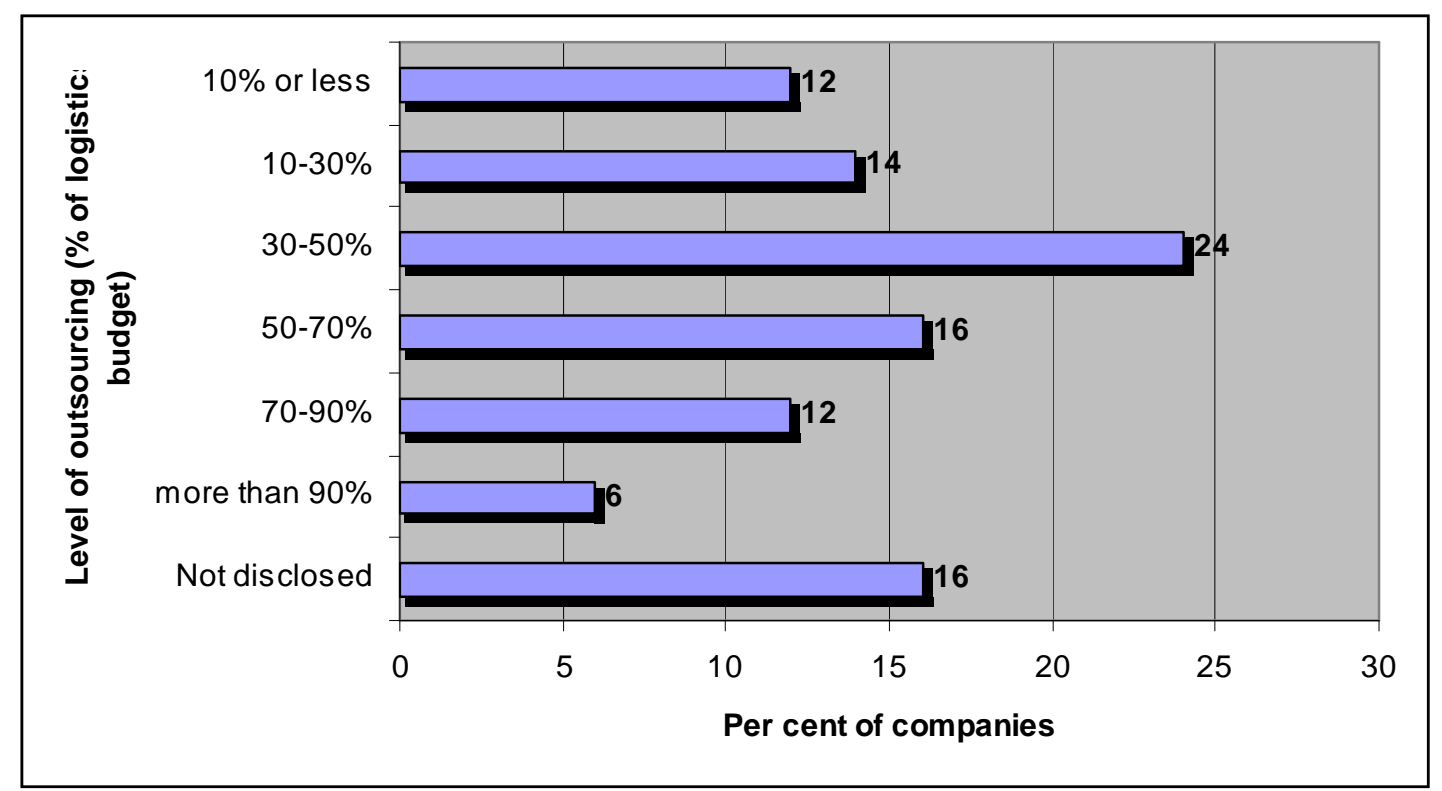

Figure 4.1. Per cent of the logistics budget outsourced.

\subsection{Why Outsource?}

In this part we discuss why consumer good companies outsource. The surveyed companies were asked to list three of their primary reasons for outsourcing. The question was closed-ended, i.e. a list of options was provided. Figure 4.2 presents the top-scoring reasons graphically. 


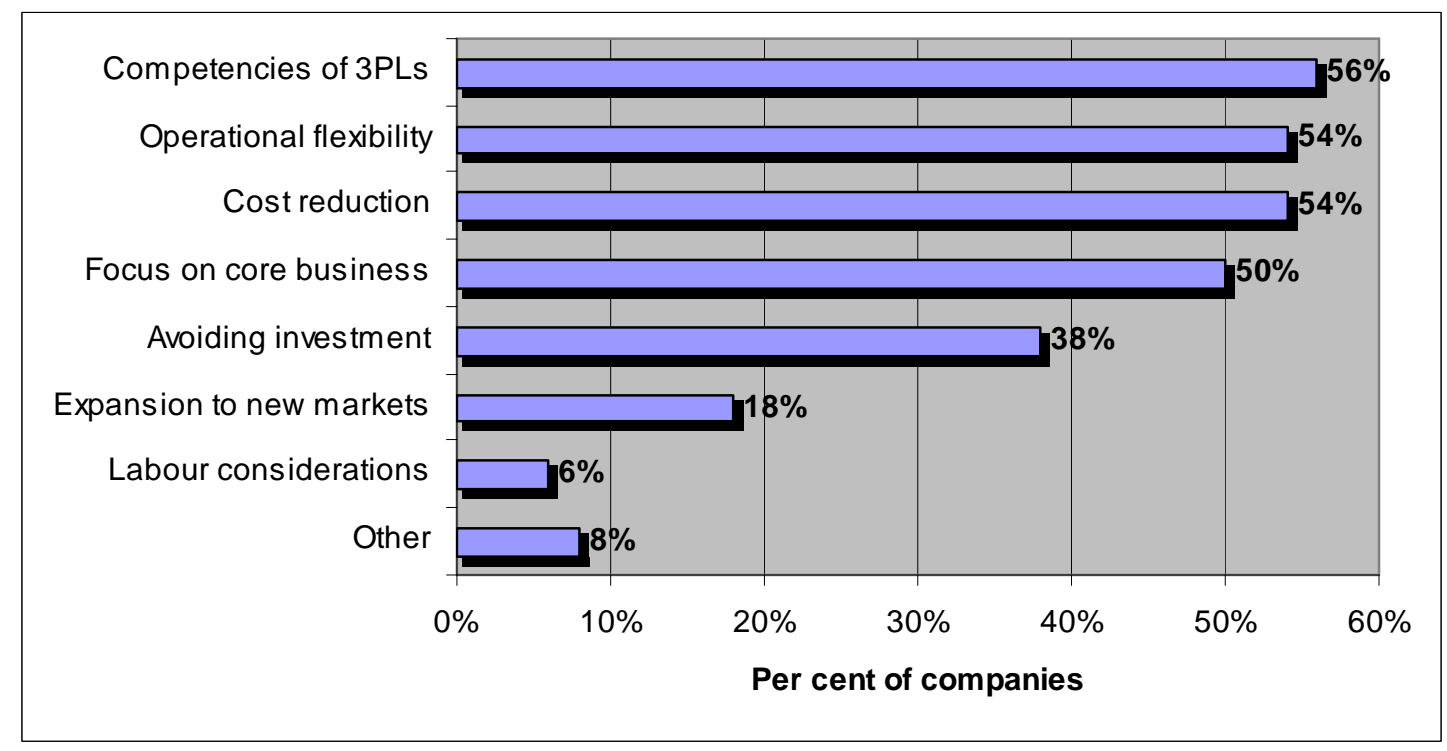

Figure 4.2. Reasons for outsourcing.

The literature review showed that costs are the single most common reason for outsourcing. However, according to this survey, consumer goods companies choose to outsource primarily in order to benefit from the competencies of 3PLs. Flexibility and cost objectives are very important too but cost reduction is definitely not an uncontested leader. There are several reasons why so few firms outsource for cost reasons:

- Primary business focus is on service, rather than cost. Of the four main drivers for outsourcing (3PL competencies, cost, flexibility and focus on core), only one is cost related. The other ones are directly or indirectly service-related, showing that service considerations dominate over cost ones. It may be argued that outsourcing decisions in the consumer goods logistics tend to be less costdriven than they are on average over all industries.

- Costs are a qualifying, not a winning factor. Companies assume low costs from 3PLs and make outsourcing decisions on other grounds, such as service. Szymankiewicz (1994) even suggests that grocery retailers take both low cost and good service from 3PLs for granted.

- 3PLs' ability to actually lower logistics costs. Our evidence suggests that consumer good companies are aware of the fact that not every outsourcing decision decreases costs and therefore they do not expect cost cuts in the first place. A profit margin charged by 3PLs is reflected in the price for the services and may mean that keeping logistics in-house is cheaper than outsourcing.

Avoiding investment ranks somewhat higher in the list of reasons than the literature review implied. A reason for that may be that the logistics of consumer goods industry requires larger investments than many other industries and companies are therefore more likely to avoid these investments by outsourcing.

Poor labour availability or quality within the surveyed organisations is not a considerable driver for outsourcing. This result is in line with the literature review and 
may be an indication that the historically adverse nature of industrial relations in the consumer goods industry has improved (Hunt 1995, p. 27).

Some survey respondents outsourced for alternative reasons that had not been included in the list. Two firms outsourced to solve capacity problems. One company was motivated by a major organisational change (de-merger) and another one was looking to find synergy with the 3PL.

4.3 What logistics functions should be outsourced?

As previously discussed, outsourcing should not be seen as an "all or nothing" kind of decision. The survey results confirm this suggestion: $72 \%$ of the survey respondents use both 3PLs and the in-house logistics department to manage at least one logistics function. There are, indeed, logistics functions, where these firms only use either 3PL or in-house department. However, the fact that almost three quarters of companies have at least one function where 3PL and in-house are combined implies that mixed systems are common.

To assess which logistics functions are seen as the best and the worst suited for outsourcing, we asked the companies whether they used 3PLs in eleven logistics areas. Table 4.1 shows the preference of survey respondents.

Table 4.1. Logistics functions most likely to be outsourced, kept in-house or managed with a mixed system (\% of companies)

\begin{tabular}{|l|l|l|}
\hline $\begin{array}{l}\text { Logistics functions most } \\
\text { commonly fully } \\
\text { outsourced }\end{array}$ & $\begin{array}{l}\text { Logistics functions most } \\
\text { commonly managed as a } \\
\text { mixed system }\end{array}$ & $\begin{array}{l}\text { Logistics functions most } \\
\text { commonly kept fully in- } \\
\text { house }\end{array}$ \\
\hline Primary transport $-68 \%$ & $\begin{array}{l}\text { Additional storage during } \\
\text { peak periods - 38\% }\end{array}$ & Carrier selection $-82 \%$ \\
\hline Secondary transport - 52\% & $\begin{array}{l}\text { Storage during off peak } \\
\text { periods - 34\% }\end{array}$ & $\begin{array}{l}\text { Logistics information } \\
\text { systems - 78\% }\end{array}$ \\
\hline $\begin{array}{l}\text { Additional storage during } \\
\text { peak periods - 36\% }\end{array}$ & Secondary transport - 30\% & $\begin{array}{l}\text { Returns and reverse } \\
\text { logistics - 56\% }\end{array}$ \\
\hline Fleet management $-36 \%$ & Primary transport - 22\% & $\begin{array}{l}\text { Storage during off peak } \\
\text { periods - 44\% }\end{array}$ \\
\hline $\begin{array}{l}\text { Re-labelling and re- } \\
\text { packaging - 26\% }\end{array}$ & $\begin{array}{l}\text { Returns and reverse } \\
\text { logistics - 20\% }\end{array}$ & $\begin{array}{l}\text { Final product } \\
\text { customisation - 42\% }\end{array}$ \\
\hline
\end{tabular}

Based on the data provided by the survey respondents, an "outsourcability" index was calculated. If all the surveyed companies had fully outsourced a logistics function, the index for that function would equal 100. In the other extreme, if all companies kept a logistics function completely in-house, the index would equal 0. Since companies were asked to reveal their share of 3PLs if they combined 3PL and in-house logistics 
department, we were able to calculate a weighted average level of outsourcing for all logistics functions. The results are presented on Figure 4.3.

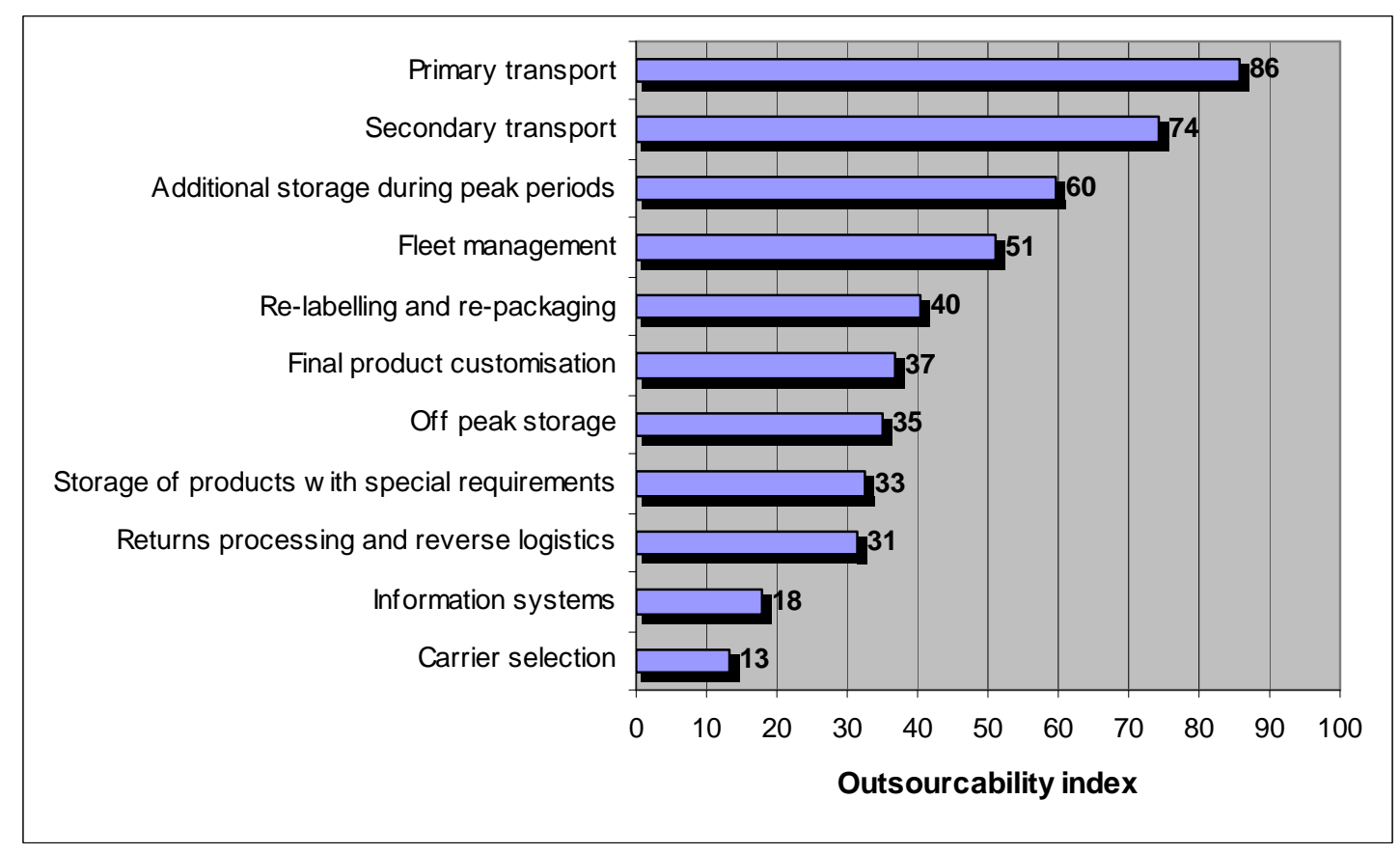

Figure 4.3 "Outsourcability” of different logistics functions.

Based on Table 4.1 and Figure 4.3, the following can be said about the outsourcing of logistics functions:

- Transport is the most likely logistics function to be fully outsourced, confirming the results of previous research.

- Carrier selection is least likely to be outsourced. The companies wish to preserve some sort of supervision of their carriers even if transport is outsourced. An interview with the logistics manager of a European beverage producer revealed that the company uses about 40 contractors on transport. Such wide selection of haulage companies to choose from adds flexibility to the producer's operations. Competition between carriers also motivates them to deliver better service quality.

- Regular storage (during off-peak seasons) is usually kept in-house or is shared between in-house and 3PL. A similar pattern is apparent for storage of products requiring special conditions, such as certain temperature range, hanging garments for companies whose main business is not clothes etc. We see two main reasons behind the dominance of in-house in regular storage. Firstly, historic reasons: many companies in mainland Europe had invested heavily in the physical logistics network before the 3PL industry had emerged. Some companies may still be reluctant to give up their facilities, even though there might be no pragmatic reason to hold on to them (Paché 1998, p. 305). Secondly, the need for facilities may be very specialist: interviews with several 
logistics managers and consultants showed that many parts of Europe lack suitable warehousing space of sufficient capacity and storage possibilities.

- Additional storage during peak periods is usually fully outsourced or comanaged by the in-house logistics department and a 3PL. This strategy implies that companies are looking for flexibility in their storage activities. While regular storage is often kept in-house to utilise the existing facilities, 3PLs are used for additional storage during the peak periods of the year, for example, before Christmas.

- Outsourcing of logistics information systems has a low priority to most consumer goods companies. The findings of the current study are in line with other research. We see three main reasons for keeping information systems inhouse. Firstly, the systems are seen as an essential element of the business. Especially major retailers have invested heavily in information systems to ensure that up-to-date POS (point of sale) data and forecasts are available. A study by Andersen Consulting found that investing in POS systems has the highest IT investment priority among retailers (Chain Store Age 2001). Secondly, 3PLs are poor at delivering high quality information systems. Gutiérrez and Durán (1997, p. 79) found that many companies are dissatisfied with the quality and integration of information provided by 3PLs. The same view was expressed by several of our interviewees. Lastly, many companies aim for systems integration, for example, logistics system with ERP Enterprise Resource Planning. This is done more easily if all systems are kept in-house.

- Relatively lower percentages in the second column of Table 4.1 indicate that mixed system tends to be less common than full outsourcing or full in-house operations.

So far we have focused on current practices. Yet, companies were also asked how they expected their 3PL and in-house balance to change over the next three years. Almost half of the respondents (46\%) expect to change the 3PL and in-house balance, that is to outsource new activities or bring some activities in-house. $40 \%$ of respondents expect no changes and the remaining $14 \%$ did not disclose their anticipations.

Of the companies that expect changes to the 3PL and in-house balance, 69\% claim that they intend to use 3PLs more than they do now. $22 \%$ plan to move logistics more in-house. The remaining 9\% intend to change the balance but not necessarily by increasing the share of one of the two, for example, by increasing 3PL use on some logistics functions and reducing on others.

The changes are most likely to occur in the areas relating to transport or warehousing with over $20 \%$ of all companies planning for modifications in those functions. Some of the 3PLs that have invested heavily to become 4PLs may find this result disappointing as their clients do not appear to see a strong need for advanced services. 


\subsection{How to manage satisfaction within a 3PL partnership?}

In the last part we present the survey results on the management of 3PL partnerships. Firstly we discuss how outsourcing has affected the service user in five areas: cost, service, personnel, added value services and industry-specific knowledge. We asked the companies to compare the values of these indicators before they had outsourced and now. See Figure 4.4 for details.

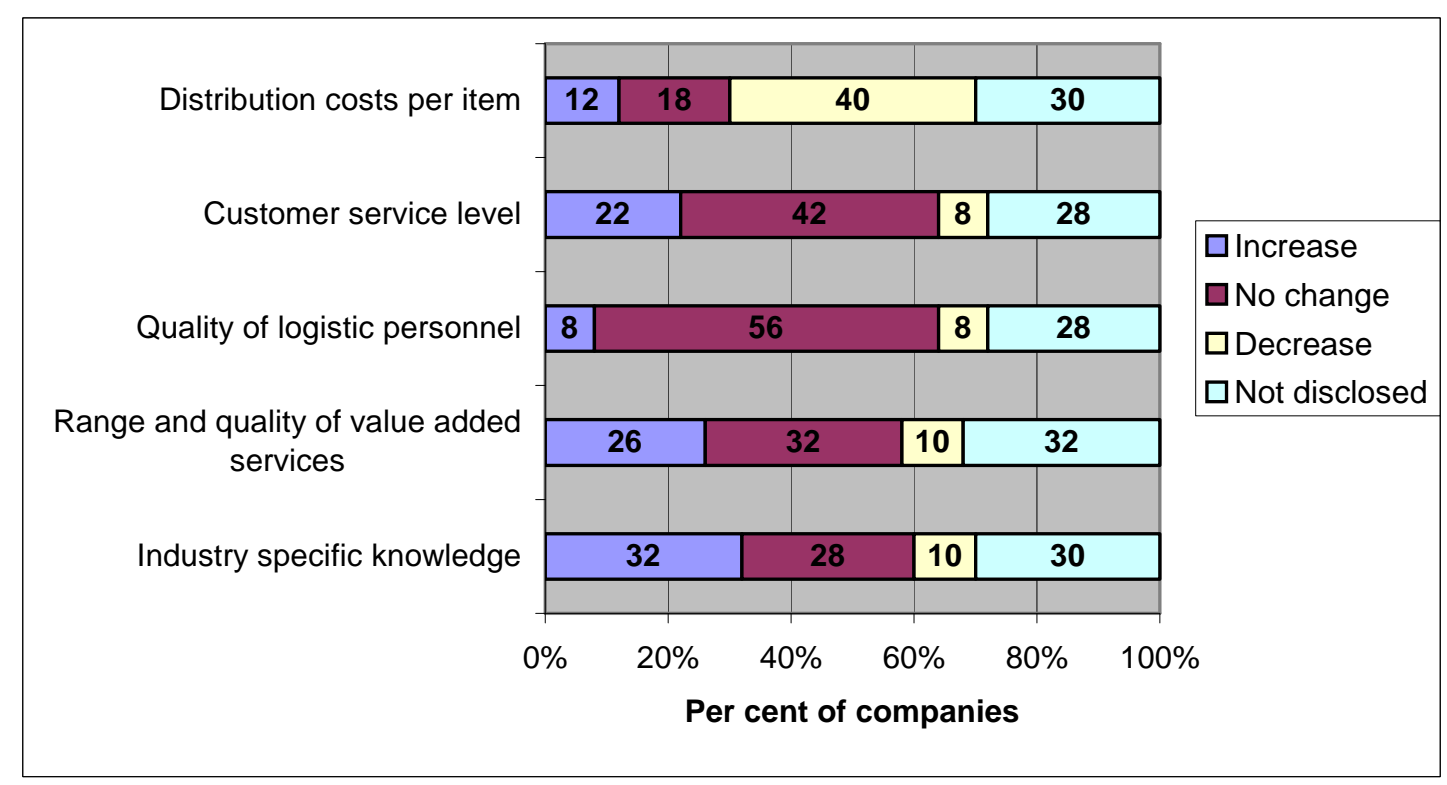

Figure 4.4. Impact of outsourcing on five aspects of logistics.

We observed that consumer goods logistics companies have generally experienced positive changes since they began to use 3PLs. The largest effect has occurred in cost containment: $40 \%$ or respondents disclosed that their average distribution costs per unit had fallen. The impact on service levels is generally positive, although the largest share of companies reports no change to service levels due to outsourcing.

We tested whether there is a correlation between the overall satisfaction with outsourced logistics services and the level of outsourcing. The logic behind the hypothesis is that if a company is more satisfied with its third parties then it can be expected to outsource a large share of its logistics activities.

Companies were asked what percentage of their logistics budget is outsourced and what changes they have experienced in five categories since they started to use a 3PL, as presented in Figure 4.4. To quantify the responses the following calculation was made: positive changes were awarded three points, no change was awarded one point and negative changes were awarded zero points. A negative change is, for instance, decrease in the service level due to 3PL use. Points were summed up and converted into an index of satisfaction, ranging from 0 to 100, where 100 indicates only positive changes in all five categories and 0 only negative changes.

The 3, 1, 0 scoring system has advantages compared to e.g. 1, 0, -1 scoring system. The latter scoring system may easily lead to a total of zero for different sets of positive and negative changes and thus neglect these differences. Also, the 3,1,0 system is a 
better representation of the expectations of a rational management that having decided to outsource logistics, expect improvements in these five aspects.

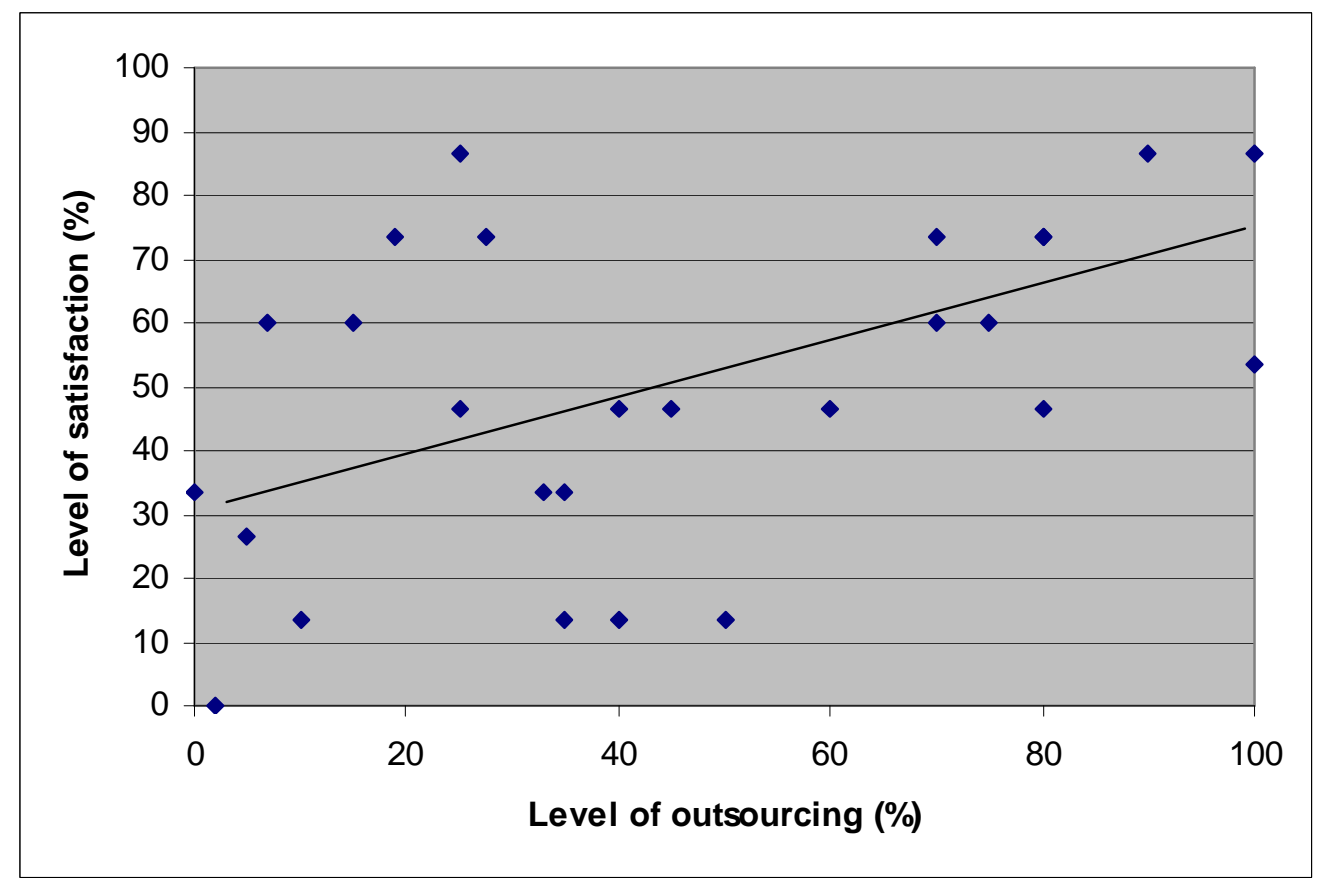

Figure 4.5. Level of satisfaction versus level of outsourcing.

The satisfaction index was plotted against the level of outsourcing on to Figure 4.5, both being expressed as on a scale from 0 to 100. Each point on the Figure 4.5 refers to one company. The relationship between the level of satisfaction and the level of outsourcing is weak (correlation coefficient of 0.48). The satisfaction index only takes into account the five aspects of change brought about by 3PL use shown on Figure 4.4. We acknowledge the fact that the scale might not explain $100 \%$ of variance, i.e. there may be other factors that influence satisfaction with logistics providers.

The following implications can be drawn from Figure 4.5:

- There is a great variety of practices: the level of outsourcing ranges from 0 to 100 per cent. Also, satisfaction ranges from 0 to 87 per cent.

- A regression line was plotted on the Figure. It can be seen that the line has a positive slope. This indicates that the hypothesis made above about the relationship between the levels of satisfaction and degree of outsourcing is indeed true. However, a fairly low correlation coefficient signals that the relationship is weak. Therefore we can see a link between an organisation's experience and outsourcing although it is not significant. The regression output is as follows:

$\begin{array}{ccccc} & \text { Coefficients } & \text { Standard error } & \text { t Statistic } & P \text {-value } \\ \text { Intercept } & 15.27009 & 11.9697 & 1.27572 & 0.21377 \\ \text { Satisfaction } & 0.604656 & 0.216788 & 2.78915 & 0.00996\end{array}$


P-values show that the coefficient for 'level of satisfaction' is statistically different to zero and the coefficient for the intercept is not at $95 \%$ confidence level.

- There are no companies in the bottom right-hand corner that denotes high level of outsourcing but low satisfaction with 3PLs. The implication is that if a company is not happy with the third party then it is likely to bring the logistics activities back in-house. This means that the companies would move to the bottom left-hand corner of the box.

It is surprising to note on Figure 4.4 how many companies have not disclosed their response to the question about level of satisfaction (32\% of the companies). This may indicate that the companies consider this information to be commercially sensitive. Another explanation is that the companies do not possess that information themselves, i.e. they have not measured what the impact of using third parties has actually been. This proposition leads to the questions of what aspects of 3PL performance are actually measured.

Measuring the performance of third parties provides valuable information about the changes that outsourcing has brought about in terms of cost, service etc. It is also critical to managing the partnership with the 3PLs.

An open-ended question in the survey addressed the use of performance measures among the respondents. Not surprisingly, a large majority (78\%) stated that they use some sort of formalised performance measurement. Only 10\% claimed the opposite, while the remaining $12 \%$ did not disclose their strategy.

Companies were asked to list the measures they use. Respondents use a wide range of performance measures, some of which are similar in essence. The most popular performance measures focus on service (indicated by 54\% of companies) and cost $(32 \%)$. In addition to the standard set of KPIs, some companies have also introduced less common measurements to match their specific needs. Performance measures listed by companies were classified and are presented in Table 4.2. Notice should be taken of the fact that as options were not provided, the respondents might not have listed the entire range of KPIs that they actually use.

Table 4.2. Use of performance measures

\begin{tabular}{|l|l|c||}
\hline $\begin{array}{l}\text { Clusters of } \\
\text { performance } \\
\text { measures }\end{array}$ & $\begin{array}{l}\text { Actual performance measures used (quoted } \\
\text { from the respondents) }\end{array}$ & $\begin{array}{c}\text { Per cent of } \\
\text { companies }\end{array}$ \\
\hline Delivery timeliness & $\begin{array}{l}\text { Delivery timeliness, delivery punctuality, delivery } \\
\text { accuracy, delivery quality, schedule adherence, } \\
\text { delivery failures, delivery performance }\end{array}$ & 46 \\
\hline Cost & $\begin{array}{l}\text { Costs per unit, full visibility of costs, cost control, } \\
\text { financial bonus-penalty system }\end{array}$ & 32 \\
\hline Overall quality & $\begin{array}{l}\text { Includes broadly defined measures such as service } \\
\text { level, quality of orders, overall quality, fleet } \\
\text { quality }\end{array}$ & 22 \\
\hline
\end{tabular}




\begin{tabular}{|l|l|c||}
\hline Inventory management & $\begin{array}{l}\text { Stock turnover, shortage claims, throughput, stock } \\
\text { accuracy, inventory difference }\end{array}$ & 20 \\
\hline Picking accuracy & Picking accuracy, picking quality & 18 \\
\hline $\begin{array}{l}\text { Responsiveness and } \\
\text { flexibility }\end{array}$ & $\begin{array}{l}\text { Reactivity, response to queries, administration, } \\
\text { customer service, flexibility to fluctuations in } \\
\text { capacity }\end{array}$ & 14 \\
\hline $\begin{array}{l}\text { Error and damage } \\
\text { assessment }\end{array}$ & Percent of damages, error rates & 14 \\
\hline Lead-time & Re-supply speed, inbound lead-time & 6 \\
\hline $\begin{array}{l}\text { Receiving/unloading } \\
\text { and despatch/loading }\end{array}$ & Despatch punctuality, unload/load time & 4 \\
\hline Documentation & Receipt accuracy & 4 \\
\hline $\begin{array}{l}\text { Variation in actual and } \\
\text { expected performance }\end{array}$ & Comparison of performance and expectations & 10 \\
\hline Other & $\begin{array}{l}\text { Product temperature, scanning accuracy, vehicle } \\
\text { utilisation, staff and customer satisfaction, units } \\
\text { per man hour }\end{array}$ & \\
\hline
\end{tabular}

Companies use many KPIs relating to costs and transport and warehouse operations. Some performance measures tend to be broadly defined. It is difficult to conceive how the actual measurement is carried out in some of these cases, for example, how fleet quality is measured.

Although performance measurement is in place in most 3PL relationships, a vast majority of companies (over 90\%) are considering further development of KPIs.

One of the most surprising findings of the survey is that $74 \%$ of the survey respondents have at least once declined from renewing a 3PL contract with the same service provider. This suggests that the majority of consumer goods companies have, at some point, been seriously dissatisfied with the services they receive from the third parties. The dissatisfaction has been so significant that the companies have chosen to switch to a different 3PL. Just $10 \%$ of respondents claim that they have never experienced problems leading to not renewing contracts with the third parties. The remaining $16 \%$ chose not to disclose their experiences.

Table 4.3 demonstrates that the top reasons for not renewing 3PL contracts relate to service and quality (indicated by $68 \%$ of companies) and cost (52\%). Almost a fifth of the companies also listed communication, trust or responsiveness to changes as a reason for non-renewal.

Table 4.3. Reasons for not renewing contracts with 3PLs

\begin{tabular}{|l|c|}
\hline Reasons & $\begin{array}{c}\text { Citing per cent } \\
\text { of companies }\end{array}$ \\
\hline $\begin{array}{l}\text { Service and quality issues: poor performance, poor service, customer } \\
\text { service problems }\end{array}$ & 68 \\
\hline Cost issues & 52 \\
\hline $\begin{array}{l}\text { Trust and communication problems: poor information flow, relationship } \\
\text { breakdown, failure to reach an agreement, culture, inability to help in a } \\
\text { crisis situation }\end{array}$ & 10 \\
\hline
\end{tabular}




\begin{tabular}{|l|c|}
\hline Change management: inability to adapt with changes, lack of innovation & 8 \\
\hline $\begin{array}{l}\text { Strategic decisions: decision to go in-house, centralisation of } \\
\text { distribution }\end{array}$ & 4 \\
\hline Poor management & 4 \\
\hline Competing offer & 2 \\
\hline Financial instability & 2 \\
\hline No value added & 2 \\
\hline Acceptability of trade credit & 2 \\
\hline
\end{tabular}

It is surprising how many companies have had disappointing experiences with third parties. This indicates that the level of 3PLs operating in Europe varies considerably. Findings discussed above suggest most companies to be satisfied with their current 3PL relationships. It appears that most consumer goods companies go through a learning phase until they find a 3PL able to provide sufficient service level.

Quality, service and cost reasons can be expected to top the list of reasons for nonrenewal. It is significant that $18 \%$ of the companies realise that 'soft issues', such as communication and trust problems may lead to the termination of a 3PL relationship. The consumer goods companies might not be willing to accept that communication and trust have been an issue because this would mean that the relationship has failed at least partially because of the user of logistics services.

\section{Conclusion}

This Europe-wide survey has provided some useful insights into the customer perceptions of 3PLs within the consumer goods sector. It revealed that outsourcing in the consumer goods industry is less cost-driven than other studies have demonstrated. Various aspects of service are more or equally important to cost in the market characterised by fierce competition and ever-increasing customer focus. The good news for managers of 3PLs is that their customers in the consumer goods industry state competences of 3PLs as the primary reason for contracting out logistics.

Our survey as well as many previous studies highlights that consumer goods companies perceive transport to be the best and information systems the worst suited for outsourcing. A large number of practices are in place for managing storage. Companies looking to outsource warehousing often face the lack of suitable facilities in terms of capacity and specialist requirements.

The combined use of 3PLs and in-house logistics department is often neglected in logistics studies. Our survey showed that over two thirds of companies actually manage at least one logistics function with such a mixed system. Given the flexibility it gives to the consumer goods companies we expect the mixed systems to become even more popular. 
Whilst the inevitability of performance measurement is repeatedly stressed in academic research, the set of KPIs actually used by consumer goods companies to assess their 3PLs has not received significant attention by researchers. We identified that delivery timeliness is the most common performance indicator. This result is expected given that transport is the most common logistics function to be outsourced. Surprisingly, though, just about one third of companies stated that they measure the 3PLs on cost.

The survey confirmed the findings of previous research in that the use of 3PLs has usually had a positive impact on companies' performance, especially on cost. At the same time, researchers often understate that outsourcing is a learning experience for a considerable number of companies. As over $70 \%$ of the consumer goods companies have at some point declined from renewing their contract with a 3PL, finding the right 3PL requires more effort than many firms expect. The primary reasons for switching 3PLs relate to service. This raises the question of how the learning experience could be made less painful: what features must be present in 3PLs to take an educated guess about the reliability of the service provider?

Further research could also address how managerial and balance of power issues are handled where both a 3PL and an in-house department manage logistics. It is worth studying the provider perceptions on the same areas of logistics outsourcing as we did on the customer perceptions. Finally, a more exhaustive list of the aspects of satisfaction with outsourcing could be studied.

\section{Acknowledgements}

The authors of this research would like to acknowledge management consultancy Kurt Salmon Associates for their sponsorship and assistance on the research.

\section{References}

Boyson, Sandor; Corsi, Thomas; Dresner, Martin and Rabinovich, Elliot. (1999). "Managing effective third party logistics relationships: what does it take?" Journal of Business Logistics, 20 (1), 73-100.

Bradley, Peter. (1994). "Contract logistics: it's all about costs", Purchasing, 20 October, 56.

Chain Store Age. (2001). "ROI: the top priority." Chain Store Age, October 2001, 5a7 a.

Dapiran, Peter, Lieb, Robert, Millen, Robert and Sohal Amrik. (1996). "Third party logistics services usage by large Australian firms." International Journal of Physical Distribution and Logistics Management, 26 (10), 36-45.

Fawcett, Stanley E. and Cooper, M. Bixby. (1998). "Logistics performance measurement and customer success." Industrial Marketing Management, 27 (4), 341357. 
Fernie, John. (1999). "Outsourcing distribution in UK retailing." Journal of Business Logistics, 20 (2), 83-95.

Food Logistics. (2002). "Shifting into gear: an exclusive survey of transport managers examines industry trends." Food Logistics, 15 March, No. 48, 25-28.

Gutiérrez, Gil and Durán, Alfonso. (1997). "Information technology in logistics: a Spanish perspective." Logistics Information Management, 10 (2), 73-79.

Hunt, David. (1995). “Developing Outsourcing Strategies in Logistics.” MSc Thesis. Cranfield University, Cranfield.

Laarhoven, Peter van, Berglund, Magnus and Peters, Melvyn. (2000). "Third-party logistics in Europe - five years later." International Journal of Physical Distribution \& Logistics Management, 30 (5), 425-442.

Millen, Robert, Sohal, Amrik, Dapiran, Peter, Lieb, Robert and Van Wassenhove, Luk N. (1997). "Benchmarking Australian firms' usage of contract logistics services: a comparison with American and Western European practices." Benchmarking for Quality Management \& Technology, 4 (1), 34-46.

MMH. (2001). “3PLs on the rise.” Modern Materials Handling, 56 (14), 15.

Murphy, Paul R. and Poist, Richard, F. (2000). "Third-party logistics: some user versus provider perspectives." Journal of Business Logistics, 21 (1), 121-133.

Paché, Gilles. (1998). "Logistics outsourcing in grocery distribution: a European perspective." Logistics Information Management, 11 (5), 301-308.

P-E International. Logistics Consulting Services (1994). "Contracting out or selling out? Survey into the current issues concerning the outsourcing of distribution." $26 \mathrm{pp}$. Also published as: Szymankiewicz, Jan. (1994). "Contracting out or selling out? Survey into the current issues concerning the outsourcing of distribution." Logistics Management, 7 (1), 28-35.

Penske Logistics (1999). "Survey finds bottom line drives outsourcing", Logistics Management \& Distribution Report, May, 1999. Pp. 24 (Survey carried out by Penske Logistics).

Razzaque, Mohammed Abdur and Sheng, Chang Chen. "Outsourcing of logistics functions: a literature survey." International Journal of Physical Distribution \& Logistics Management, 28 (2), 89-107.

Sohail, Sadiq and Sohal, Amrik. (2003). "The use of third party logistics services: a Malaysian perspective." Technovation. 23 (5), 401-408.

Wong, Yim-Yu, Maher, Thomas, Nicholson, Joel D. and Gurney, Nicholas P. (2000). "Strategic Alliances in Logistics Outsourcing." Asia Pacific Journal of Logistics and Marketing, 12 (4), 3-21. 